\title{
Aspects of Reproduction in the Southern Flying Squirrel in Florida
}

\author{
Mendi A. V. RAYMOND \& James N. LAYNE
}

Raymond M. A. V. \& Layne J. N. 1988: Aspects of reproduction in the southern flying squirrel in Florida. Acta theriol., 33, 37: 505-518. [With 2 Tables \& 2 Figs.]

Breeding season, litter size, nestling sex ratio, and breeding histories of individual females of the southern flying squirrel (Glaucomys volans) in south-central peninsular Florida were studied by use of nest boxes from July 1979 through May 1984. Estimated parturition dates of 93 litters of 81 females ranged from the third week of August through the second week of January; with major peaks in August-early Sept. and late Sept.-early Nov. and a minor peak in mid-December. Mean litter size over all years was 3.0 (range $=1-6)$. Younger litters had a significantly higher mean size (3.5) than older litters (2.8). Over the five-year period there was less variation in the time of first parturition each year than in the distribution of births during the breeding season and the timing of the last birth, with 1982-83 differing significantly from all other years. Young in litters $(n=282)$ consisted of $52 \%$ males and $48 \%$ females. Although there was a suggestion of a decreasing proportion of males in litters from late summer to winter, seasonal differences were not significant. During their known residence on the study area, 71 of 81 females had a single litter in nest boxes, 8 had two, and 2 had three. Only one possible case of a female producing two litters in a year was recorded. The data support the hypothesis that the breeding season of the southern flying squirrel shifts from spring-fall in northern latitudes to late summer-winter in the southern part of its eastern North American range. However, mean litter size in the Florida population was not smaller than reported values from more northerly regions, in contradiction to the hypothesized trend of reduction of litter size with decreasing latitude.

[Archbold Biological Station, P. O. Box 2057, Lake Placid, Florida 33852 , USA].

\section{INTRODUCTION}

The southern flying squirrel, Glaucomys volans (Linnaeus, 1758), occupies an extensive geographic range that includes southeastern Canada, eastern United States south to southern peninsular Florida and west to eastern Texas, and from central Mexico to Honduras (Hall, 1981). As a result of the widely varying environmental conditions occurring in different parts of its large range, the species is a useful subject for examining the influence of habitat, climate, and other environmental variables 
on life history parameters. Previous studies in different regions in the eastern United States (e.g. Moore, 1942, 1947; Sollberger, 1943; Muul, 1969, 1970, 1974; Goertz et al., 1975; Heidt, 1977; DeCoursey, 1978; Linzey \& Linzey, 1979; Sonenshine et al., 1979; Sawyer \& Rose, 1985) have suggested the existence of latitudinal trends in certain aspects of reproduction in this species. The two major hypotheses that have been presented are: (1) the breeding season shifts from spring to late summer in the north to late summer through late winter in the south (DeCoursey, 1978) and (2) litter size decreases with decreasing latitude (Goertz et al., 1975; Sawyer \& Rose, 1985). The objectives of this study were to further test these hypotheses by examining breeding season and litter size in south-central Florida near the southernmost limit of the North American range and to obtain further knowledge of other aspects of the reproductive biology of this species in Florida.

\section{MATERIAL AND METHODS}

The study was conducted on a 400 -ha tract of the Archbold Biological Station, $12 \mathrm{~km}$ south of Lake Placid, Highlands County, Florida $\left(27^{\circ} 10^{\prime} \mathrm{N}\right.$ lat., $81^{\circ} 20^{\prime} \mathrm{E}$ long.). Five major vegetation associations (Abrahamson et al., 1984) were represented in the study area, which had not been burned since 1927. These included (percentage of total area in parentheses) southern ridge sandhills $(23 \%)$, sand pine scrub $(35 \%)$, scrubby flatwoods $(26 \%)$, flatwoods $(12 \%)$, and bayhead $(1 \%)$. The first three communities were on sandy well-drained soils and were relatively xeric. The dominant tree species were sand pine (Pinus clausa) and slash pine $(P$. elliottii). Although pines occurred in dense stands in some parts of the sand pine scrub association, they generally were widely-spaced, particularly in scrubby flatwoods. Sandhill, scrub, and scrubby flatwoods habitats were characterized by a relatively dense shrub understory consisting of oaks (Quercus laevis, Q. geminata, Q. myrtifolia, and Q. inopina), scrub hickory (Carya floridana), and palmettos (Serenoa repens, Sabal etonia). Flatwoods were on less well-drained soils with slash pine as the dominant tree. The distribution of pines varied from dense to very open, and the understory ranged from open glades of wire grass (Aristida stricta) or cutthroat grass (Panicum abscissum) to dense shrubs (Ilex glabra, Lyonia lucida, L. fruticosa) and saw palmetto. The bayhead was the most mesic of the plant communities, with soils containing a muck layer. Broad-levaed evergreens, including loblolly bay (Gordonia lasianthus), sweet bay (Magnolia virginiana), and red bay (Persea borbonia), were the principal components of the tree layer, with occasional slash pines. Ferns (Osmunda cinnamonea, O. regalis, Woodwardia virginica) were abundant in the understory, and the ground was covered by a thick layer of leaves and pine needles reaching a depth of 30 to $60 \mathrm{~cm}$ around the base of some trees. Flying squirrels were present in all of these habitats, with no evidence of marked differences in population levels in different vegetation associations.

Data were obtained from litters in 114 nest boxes placed on trees at heights of 1.5 to $5.3 \mathrm{~m}$ throughout the study area. Eighty-nine boxes were spaced at 
approximately $120-\mathrm{m}$ intervals along a network of firelanes and woods roads extending through the study area, with the number of nest boxes in each habitat being roughly proportional to the amount of that habitat in the study area. The remaining 25 boxes were located at the corners and centers of five 2.8 -ha small mammal grids in the major vegetation types. Nest boxes were of the type described by Barkalow \& Soots (1965), with the exception that the entrance size $(6.4 \mathrm{~cm})$ was reduced to $3.2 \mathrm{~cm}$ in 56 boxes to exclude their use by gray squirrels (Sciurus carolinensis). Ninety-two of the 93 flying squirrel litters occurred in the small hole boxes. Data obtained from 30 bimonthly checks (January, March, May, July, September, November) of the boxes from July 1979 through May $1984(3,420$ nest box months) were used in the present analysis.

Squirrels were marked with numbered monel metal ear tags (No. 1 size). Nestlings too small to be ear tagged were marked by toe clipping and ear tagged later if recaptured at a larger size. Three age classes were recognized on the basis of weight: nestlings $(<25.0 \mathrm{~g})$, subadults $(25.1-50.0 \mathrm{~g})$, and adults $(>50.0 \mathrm{~g})$. Based on Linzey \& Linzey's (1979) growth data from Alabama and weights at known ages of two young from the locality of this study given by Rand \& Host (1942), these categories correspond roughly to age ranges $<4$ weeks, $5-8$ weeks, and $>8$ weeks, with the upper limits of the nestling and subadult age classes approximating the weights at weaning and sexual maturity, respectively.

Parturition dates were calculated by back-dating from estimated ages of litters obtained by comparing the mean weight of young in the litter with the growth curve of body weight given by Linzey \& Linzey (1979) and supplemented by the data from Rand \& Host (1942). Because of the potential errors in this procedure, including the fact that the growth data were for laboratory-raised young mainly from a different geographic region plus the usual variability in growth rates of young, particularly at older ages, parturition dates were estimated only to the nearest week.

For purposes of analysis, two age categories of litters were recognized: (1) young litters - an adult female with nestlings, and (2) old litters - an adult female and subadults assumed to be a family group still in association. A total of 93 litters of 81 females was examined, including $33(35 \%)$ young litters and $60(65 \%)$ old litters as defined above.

\section{RESULTS}

\subsection{Breeding Season}

For all years combined, estimated parturition dates ranged from the third week of August through the second week of January, a span of 20 weeks (Fig. 1). Adding 40 days for gestation (Sollberger, 1943) at the beginning of this period and 5 weeks for weaning (Linzey \& Linzey, 1979 ) at the end, gives an overall breeding season for this population of 32 weeks, extending from the first week of July to the fourth week of February. Three peaks of births were evident in the combined data: major peaks in August - early September and late September - early November and a lesser, poorly-defined period in mid-December. Forty- 
three percent $(n=40)$ of the litters were born in late summer (third week of August - third week of September), $49 \%(n=46)$ in fall (fourth week of September - fourth week of November) and $8 \%(n=7)$ in winter (first week of December - second week of January).

The seasonal pattern of births varied from year-to-year (Fig. 1). Although the first births occurred at approximately the same time each year (third or fourth week of August), the latest parturition in different years varied by 11 weeks, ranging from the fourth week of October in 1982 to the second week of January in 1981. The average time of births in different years varied from between the fourth week of August and first week of September in 1982 to between the third and fourth weeks of October in 1980. In three of the five years $(1980-81,1981-82$, $1983-84), 74 \%$ or more of the litters were born during the fall and winter periods; whereas, in the other two years $(1979-80,1982-83)$ a higher proportion of births occurred in late summer. However, only

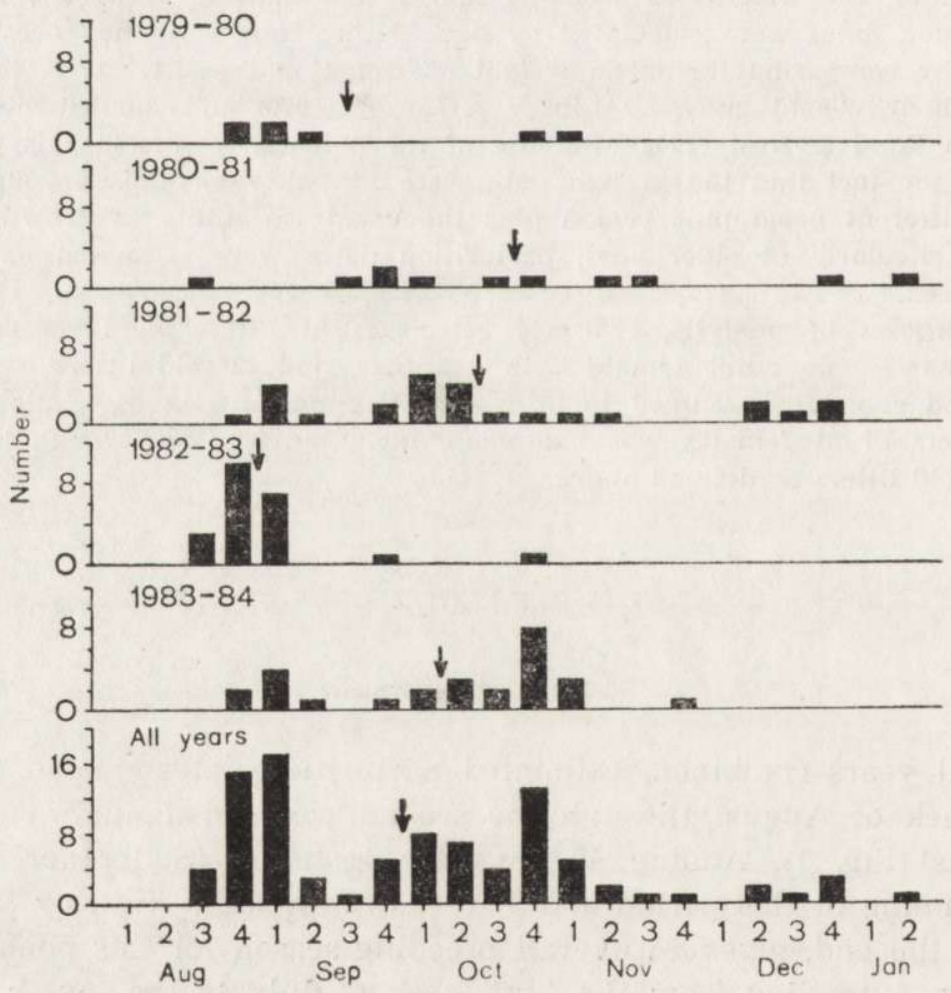

Fig. 1. Estimated parturition dates to nearest week of southern flying squirrel litters in nest boxes in south-central Florida. Arrows indicate average time of birth. 
1982-83 differed significantly from the other years in the seasonal frequency of births $\left(\chi^{2}=26.97\right.$, d.f. $\left.=1, p<0.001\right)$. The average time of births in $1982-83$ was four weeks earlier than the five-year average.

\subsection{Litter Size}

The mean of combined young and old litters was 3.0 (range $=1-6$ ). The means of young (3.5) and old (2.8) litters were significantly different $(t=3.33$, d.f. $=91, p<0.002)$. Mean size of combined young and old litters exhibited a seasonal trend as follows: late summer period, $3.3(n=40)$; fall, $2.9(n=46)$; and winter, $2.3(n=7)$. Although differences between the means of adjacent periods were not significant $(p>0.05)$, the late summer mean was significantly higher than that (2.8) of fall and winter litters combined ( $t=1.99$, d.f. $=91, p<0.05$ ). Both young and old litters showed the same trend of decreasing mean litter size as the breeding season progressed, with the means of young litters being higher in each period and showing less decline between late summer and fall - winter than those of old litters $(3.5-3.0$ vs $2.9-2.0)$. However, only the late summer means of young and old litters were significantly different $(t=2.04$, d.f. $=38, p<0.05)$.

Over all years, combined mean litter size ranged from 2.7 to 3.2 and means of young and old litters from 3.2 to 4.1 and 2.4 to 3.3 , respectively (Table 1). None of the differences in young and old litter sizes between years (young litters in 1979-80 eliminated because of small sample size) were significant (young litters $-\chi^{2}=4.85$, d.f. $=3, p>0.05$; old litters $\chi^{2}=7.90$, d.f. $=4, p>0.05$; Kruskal-Wallis one-way ANOVA, Siegel, 1956).

Table 1

Yearly means of litter size (numbers of litters in brackets) and seasonal sex ratios of young (number of males: number of females) of southern flying squirrels in south-central Florida.

\begin{tabular}{lccccccccr}
\hline Year & \multicolumn{5}{c}{ Litter size } & & \multicolumn{3}{c}{ Sex ratios } \\
\cline { 2 - 3 } & $\begin{array}{c}\text { Young } \\
\text { litters }\end{array}$ & $\begin{array}{c}\text { Old } \\
\text { litters }\end{array}$ & $\begin{array}{c}\text { Combined } \\
\text { litters }\end{array}$ & $\begin{array}{c}\text { Late } \\
\text { summer }\end{array}$ & $\begin{array}{c}\text { Fall- } \\
\text { winter }\end{array}$ & Total \\
\hline $1979-80$ & $(2)$ & 3.5 & $(5)$ & 2.6 & $(7)$ & 2.8 & $8: 7$ & $0: 5$ & $8: 12$ \\
$1980-81$ & $(5)$ & 3.4 & $(6)$ & 2.7 & $(11)$ & 3.0 & $5: 1$ & $10: 17$ & 15.18 \\
$1981-82$ & $(8)$ & 3.3 & $(18)$ & 2.4 & $(26)$ & 2.7 & $9: 10$ & $27: 24$ & $36: 36$ \\
$1982-83$ & $(8)$ & 4.1 & $(14)$ & 2.7 & $(22)$ & 3.2 & $40: 28$ & $3: 0$ & $43: 28$ \\
$1983-84$ & $(10)$ & 3.2 & $(17)$ & 3.3 & $(27)$ & 3.2 & $11: 12$ & $34: 31$ & $45: 43$ \\
All years & $(33)$ & 3.5 & $(60)$ & 2.8 & $(93)$ & 3.0 & $73: 58$ & $74: 77$ & $147: 135$ \\
\hline
\end{tabular}




\subsection{Sex Ratios of Young}

The total of 282 young in litters consisted of $52 \%$ males and $48 \%$ females (1.09:1), the sex ratio not differing significantly from equality $\left(\chi^{2}=0.51\right.$, d.f. $\left.=1, p>0.05\right)$. Sex ratios of young and old litters, 1.02:1 $(n=115)$ and 1.14:1 $(n=167)$, respectively, were not significantly different $\left(\chi^{2}=0.24\right.$, d.f. $\left.=1, p>0.05\right)$. Sex ratios of young and old litters combined (Table 1) suggested a higher proportion of males in late summer $(1.26: 1)$ than in the fall-winter period $(0.96: 1)$ as well as rather pronounced year-to-year fluctuations $(0.66: 1-1.54: 1)$. However, the differences were not significant in either case (seasons $-\chi^{2}=1.29$, d.f. $=1, p>0.05$; years $-\chi^{2}=3.36$, d.f. $=4, p>0.05$ ).

\subsection{Breeding Histories of Individual Females}

Seventy-one $(88 \%)$ of the 81 mothers of litters in nest boxes were known to have had only a single litter during the period $1979-84$. Ten $(12 \%)$ females had more than one litter in the boxes. Of these, eight individuals had two litters at intervals of (number of cases in parentheses) 10 months (2), 12 months (2), 14 months (1), 22 months (1), 24 months (1), and 26 months (1). Two females had three litters each at intervals of 10 and 14 months and 2 and 10 months, respectively.

Thirty-six females recorded with litters in the boxes in one or more years were found in boxes without litters during the peak breeding period (September - November) in other years, suggesting either that they had not bred in those years or, more likely, had born litters outside of nest boxes. Of 31 females that had a single litter in nest boxes during the five-year period, 29 were found in boxes without litters during the breeding season in one other year, one in two other years, and one in three other years. Of five females recorded with litters in nest boxes in two or three years, three individuals were in nest boxes without litters during the breeding period in one other year and two were without litters in two other years.

The only evidence of a female bearing two litters during the same breeding season was an individual in 1981 found with a litter of three young of 28 days estimated age on 28 September and with a litter of four young of 17 days estimated age on 25 November in the same nest box. Backdating to estimated birth dates indicates the litters were born approximately 69 days apart, with the second litter being conceived when the first young were approximately 1 month old. It is not known if the first litter was raised successfully, as none of the young was subsequently recaptured in nest boxes as a subadult or adult. 
Six of the 81 females found with litters in nest boxes had been originally marked as subadults. The minimum age at first breeding among this group was 10 months for an individual estimated to be 8 weeks old when first captured 25 November 1981 and found with a litter of estimated age 3 days on 8 September 1982. The other females were 14 ( 1 individual), 20 ( 1 individual), and 22 ( 3 individuals) months of age at the estimated time of conception of their first litters in nest boxes. The 20 and 22-months-old individuals had probably bred earlier outside the nest boxes.

\section{DISCUSSION}

Several lines of evidence indicate that most reproduction on the study area occurred outside of the nest boxes. Only $16 \%$ of the subadults occurring in aggregations of flying squirrels found in boxes in late fall and early winter were marked as litters in boxes. Forty-nine of 71 females $(69 \%)$ who had litters in boxes in only one year were recorded as adults in aggregations in one to four other years, showing that they had survived and probably bred more than one year. Only seven of ten females that had two or three litters in nest boxes in different years were present with litters in consecutive years. Finally, the number (81) of different females found in nest boxes with litters over the five-year period was very low compared to the number (962) of adult females that occurred in aggregations.

Flying squirrels were recorded using both tree cavities and outside nests on the study area, but we obtained no quantitative data on abundance of cavities or relative use of cavities and outside nests in different habitats. However, general observations indicated that tree cavities were more numerous in southern ridge sandhill and flatwoods than in sand pine scrub and scrubby flatwoods habitats and that Glaucomys made greater use of cavities in the first two habitats and of outside nests in the latter two associations. Flying squirrels released from live traps in the bayhead habitat often went into thick accumulations of pine needles and other litter around the base of trees rather than climbing trees as in other habitats. In some cases the squirrel was seen entering a distinct hole which led to a tunnel system within the litter. These observations suggest that flying squirrels in the bayhead habitat regularly used surface or below ground nests.

That only a small proportion of the breeding females apparently used nest boxes each year raises a question as to the degree to which reproductive data derived from the nest box samples were representative of the population as a whole. One indication that the nest box sample was 
representative of the general population is the fact that the breeding season based on estimated ages of unmarked subadults, presumably born outside nest boxes, was in reasonable agreement with that based on litters found in nest boxes. Unlike the case of breeding season, the data do not permit an independent estimate of mean litter size in natural nest sites for comparison with values for nest box litters. It is possible that litters in nest boxes and natural sites (tree cavities or outside nests) may experience differential mortality with age, which would in turn affect estimates of mean litter size based on combined samples of litters of different ages. These constraints should be kept in mind when evaluating reproductive data from this and other studies based on nest box samples.

For all years combined, the period of estimated births in the southcentral Florida population extended from mid-August to mid-January, with two periods of noticeably increased frequency of births (late August - September and October) and a third slight increase in mid-December. The extent to which the overall distribution of births reflects the typical seasonal pattern of breeding in the population is questionable, as only in 1981-82 did the seasonal distribution of births agree closely with the five-year composite.

Although the beginning of the breeding season varied by not more than two weeks from year to year, the length of the breeding season and distribution of births during the period differed considerably between years. The more pronounced variation in seasonal distribution of births appeared to be related to winter temperature and precipitation during the preceding season. Thus, the early breeding seasons of $1979-80$ and 1982-83 were preceded by mild winters and high winter - summer rainfall. The prolonged $1981-82$ breeding season, with a high proportion of late births, followed an unusually cold and dry winter. Temperature and rainfall probably affect the breeding season indirectly through their effect on food resources rather than directly influencing reproductive physiology. Warm winters and high rainfall, particularly in winter, might stimulate increased production of foods such as blossoms, buds, seeds, fungi, and insects utilized by flying squirrels (Sollberger, 1943; Muul \& Alley, 1963), with the result that the animals are in a better nutritional state and capable of breeding earlier the following season. Layne (1974) attributed winter breeding in cotton rats (Sigmodon hispidus) in certain years in north-central Florida to wetter, warmer conditions that increased the supply of green vegetation available.

Older litters tended to be smaller than young litters, presumably a reflection of the increased probability of mortality in litters with age. Age-related mortality also may account, in part, for the observed trend 
of decreasing litter size during the breeding season, as samples of litters from later in the period contained more old (as defined by weight) litters. However, the seasonal trend was still evident when young and old litters were considered separately, although the difference in mean young litter size early (3.5) and late (3.0) in the season was less than that between means of old litters $(2.9$ vs 2.0$)$. The greater seasonal difference in size of old litters may reflect a shift in the actual age composition of the old litter class from the early to late part of the breeding season. Only $11 \%$ of the old litters in the early part of the breeding season were estimated to be six or more weeks of age compared with $63 \%$ of the late season old litters. By six weeks of age, young may be venturing outside the nest (Sollberger, 1943) and thus be more vulnerable to predation. Some members of the litter also may begin to disperse after six weeks of age. The persistence of a lower mean litter size later in the breeding season among young litters, which were not subject to the same age bias as old litters, suggests that age-related mortality or dispersal of older young is not the full explanation of the seasonal trend. The late-breeding cohort may have contained a higher proportion of primiparous females, which may tend to have smaller litters than older females.

Mean size of young litters, which provides a better basis for comparison than old litters for reasons given above, did not differ significantly over years, although the highest value (4.1) occurred in 1982-83, correlating with the early breeding season that year. This supports the suggestion that breeding females may have been in a better-than-average nutritional state that year as the result of increased food resources during the preceding winter and spring.

Comparison of the reproductive data from this study with those reported from other parts of the range is complicated by differences in methods of study, very small sample sizes in some cases, and wide variation in the length of studies and intensity of sampling. Inclusion of data from captives also may bias estimates of reproductive parameters of a given population (Myers \& Master, 1986). For example, in Linzey \& Linzey's (1979) study in Alabama, the breeding season was longer in captivity than in the wild population, and their reported mean litter size might have been higher than in the wild population because of the inclusion of data from captives in the calculation (Sawyer \& Rose, 1985). Most litter sizes reported for different populations of $G$. volans are based on litters of varying ages found in natural nests or nest boxes. If the trend of decreased size of older litters observed in this study also occurs in other populations, differences between studies in the age distribution of litter samples could thus affect mean litter 
size estimates irrespective of other factors. Probably the best estimate of mean litter size in a population is provided by embryo counts, but unfortunately such data for flying squirrels are limited. Finally, as evident in this study, the seasonal pattern of breeding in a given locality may vary considerably from year-to-year, and some indication of the extent of such variation within populations is necessary to assess the significance of differences between populations. These qualifications must be kept in mind in the following consideration of geographic trends in flying squirrel reproduction

The late summer to late winter breeding season in the south-central Florida population closely agreed with other southern populations below $32^{\circ} \mathrm{N}$ latitude and contrasts with northern populations in which breeding occurs from spring to fall, usually with separate spring and fall periods (Fig. 2). The present data thus support the hypothesis of a latitudinal shift in the timing of $G$. volans reproduction in North America. Laboratory experiments and field observations by Muul (1969) indicated that reproduction in flying squirrels in northern regions (Michigan and Mas-

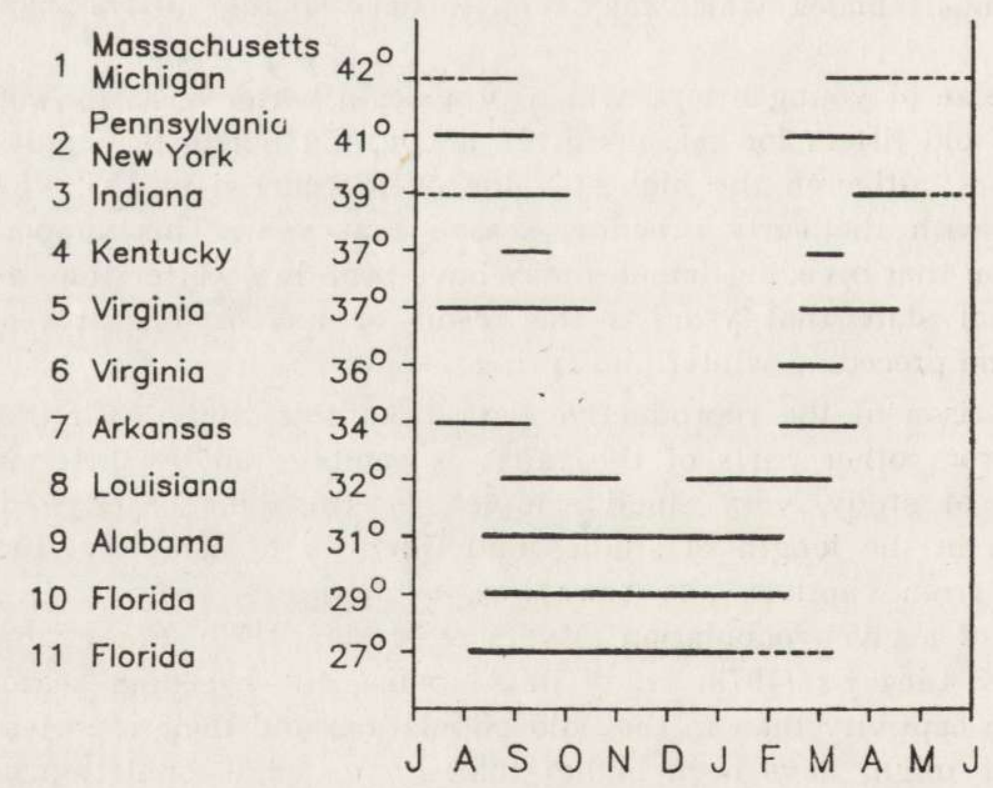

Fig. 2. Parturition periods of southern flying squirrels at different latitudes (reported mating dates adjusted to parturition dates by adding 40 days for gestation). Dashed lines indicate probable extension of the season. Data sources as follows: (1) Muul, 1969; (2) Sollberger, 1943; (3) Mumford \& Whitaker, 1982; (4) Hibbard, 1935; (5) Sonenshine, et al., 1979; (6) Sawyer \& Rose, 1985; (7) Heidt, 1977; (8) Goertz et al., 1975; (9) Linzey \& Linzey, 1979 (based on data for wild population); (10) Moore, 1942, (11) present study. 
sachusetts) was correlated with increasing photoperiod, although the annual minimum photoperiod might have been the actual cue. He doubted that reproduction in these populations was influenced by food availability, as food resources were at a low point during the spring breeding peak. In contrast, breeding in southern populations is associated with decreasing photoperiod. This difference may reflect genetic differences in the response of the reproductive physiology of northern and southern populations to day-length or, more likely, that the influence of photoperiod on reproduction in this species can be overridden by other environmental factors such as an abundance of food or favorable weather conditions. Nelson (1987) has reviewed abundant evidence for microtines of the masking of a photoperiodic affect on reproduction by nutritional factors. Late summer - winter breeding of flying squirrels in Florida is correlated with the period of maximum abundance of acorns, hickory (Carya spp.) nuts, and palmetto (Sabal etonia, Serenoa repens) fruits and thus may be related to nutritional level as well as warmer fall and winter temperatures. A similar breeding season is also exhibited by populations of other granivorous rodents such as Peromyscus gossypinus and Podomys floridanus in Georgia and Florida (Odum, 1955; Pournelle, 1952; Layne, 1974). Winter food supplies in the south may also be generally more abundant and/or available than in the north (Goertz et al., 1975).

Table 2

Mean litter size of Glaucomys volans at different latitudes in eastern United States.

\begin{tabular}{|c|c|c|c|c|c|}
\hline Locality & $\left({ }^{\circ} \mathrm{N}\right)$ & Mean & Range & $\mathbf{N}$ & Source \\
\hline Mich./Mass. & 42 & 3.2 & $2-5$ & 17 & Muul, 1974 \\
\hline Penn./New York & 41 & 3.1 & $1-4$ & 18 & Sollberger, 1943 \\
\hline Illinois & 40 & 3.3 & $2-5$ & 6 & Jordan, 1956 \\
\hline Indiana & 39 & 3.1 & $2-5$ & & $\begin{array}{l}\text { Mumford \& Whitaker, } \\
1982\end{array}$ \\
\hline 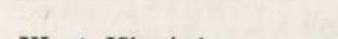 & & $4.7^{1}$ & $3-6$ & 3 & \\
\hline West Virginia & 38 & 2.9 & & 29 & Uhlig, 1956 \\
\hline & & $\begin{array}{l}3.9^{1} \\
3.4^{2}\end{array}$ & $1-6$ & $\begin{array}{l}29 \\
58\end{array}$ & \\
\hline Kentucky & 37 & 2.9 & $2-4$ & 8 & Hibbard, 1935 \\
\hline Virginia & 36 & 1.7 & & 3 & Sawyer \& Rose, 1985 \\
\hline Arkansas & 34 & 2.0 & $1-3$ & 5 & Heidt, 1977 \\
\hline Louisiana & 32 & 2.1 & $1-4$ & 41 & Goertz et al., 1975 \\
\hline Alabama & 31 & $3.2^{3}$ & $2-6$ & 24 & Linzey \& Linzey, 1979 \\
\hline Florida (north-central) & 29 & 2.6 & $1-4$ & 7 & Moore, 1942 \\
\hline Florida (south-central) & 27 & 3.0 & $1-6$ & 93 & present study \\
\hline
\end{tabular}

Embryo counts

2 Combined young and embyro counts

3 Includes wild and captive-born young 
Data on litter size for the south-central Florida population do not support the hypothesis of reduced litter size with decreasing latitude. Mean litter size was larger than that reported from some northern populations (Table 2). Mean litter sizes (excluding embryo counts) reported in the 12 studies listed in Table 2 were not significantly correlated with latitude $\left(r_{s}=0.47\right.$, d.f. $=10, p>0.05$, Spearman's rank correlation, Siegel 1956).

Little information is available on age at maturity of female flying squirrels in different parts of the range. In Virginia, most females became pregnant at 6-8 months of age (Sonenshine et al., 1979). In this study, the minimum known breeding age among six females marked as subadults was 10 months (one individual).

Wood (1910) noted that flying squirrels in the north were alleged to produce one litter a year, while those in the south might have as many as three. Although captive females may produce two or three litters in a single year (Linzey \& Linzey, 1979), evidence for females in the wild having more than one litter per year is scarce. Hibbard (1935) captured a female with four embryos in a nest with four two-thirdsgrown young in Kentucky. In Virginia, 5 of 27 females became pregnant for a second time 6 months post-partum (Sonenshine et al., 1979). Linzey \& Linzey (1979) documented a possible case of superfetation in G. volans. A single instance of a female apparently giving birth to two litters in the same breeding season was recorded in this study. However, it is possible that one of the litters had been adopted, as Muul (1970) noted that female flying squirrels have a strong tendency to retrieve both their own as well as strange young less than 40 days of age.

Acknowledgments: We thank Dorothy E. Carter for typing the manuscript and David R. Smith and Chester E. Winegarner for assistance in checking nest boxes.

\section{REFERENCES}

1. Abrahamson W. G., Johnson A. F., Layne J. N. \& Peroni P. A., 1984: Vegetation of the Archbold Biological Station, Florida: an example of the southern Lake Wales Ridge. Quart. J. Florida Acad. Sci, 47: 211-250.

2. Barkalow F. S. \& Soots R. F., Jr., 1965: An improved gray squirrel nest box for ecological and management studies. J. Wildl. Mgmt., 29: 679-684.

3. DeCoursey P., 1978: Latitudinal variation in reproductive patterns of the southern flying squirrel (Glaucomys volans). Abstr. Tech. Paper 58th Ann. Meeting Amer. Soc. Mamm., 13-17 June 1978.

4. Goertz J. W., Dawson R. M. \& Mowbray E. E., 1975: Response to nest boxes and reproduction by Glaucomys volans in northern Louisiana. J. Mamm., 56: 933-939.

5. Hall E. R., 1981: The mammals of North America. John Wiley and Sons, New York. $1-1875$.

6. Heidt G. A., 1977: Utilization of nest boxes by the southern flying squirrel 
Glaucomys volans in central Arkansas. Proc. Arkansas Acad. Sci., 31: 55-57.

7. Hibbard C. W., 1935: Breeding seasons of gray squirrel and flying squirrel. J. Mamm., 16: 325-326.

8. Jordan J. S., 1956: Notes on a population of eastern flying squirrels. J. Mamm., 37: 294-295.

9. Layne J. N., 1974: Ecology of small mammals in a flatwoods habitat in northcentral Florida, with emphasis on the cotton rat (Sigmodon hispidus). Amer Mus. Novitates, 2544: $1-48$.

10. Linzey D. W. \& Linzey A. V., 1979: Growth and development of the southern flying squirrel (Glaucomys volans volans). J. Mamm., 60: 615-620.

11. Moore J. C., 1942: A survey of the mammals of the University of Florida Conservation Reserve. Unpubl. M.S. thesis, Univ. Florida, Gainesville. 1-164.

12. Moore J. C., 1947: Nests of the Florida flying squirrel. Amer. Midland Nat, 38: $248-253$.

13. Mumford R. F. \& Whitaker J. O., Jr., 1982: Mammals of Indiana. Indiana Univ. Press, Bloomington. 1-537.

14. Muul I., 1969: Photoperiod and reproduction in flying squirrels, Glaucomys volans. J. Mamm., 50: 542-549.

15. Muul I., 1970: Intra- and inter-familial behavior of Glaucomys volans (Rodentia) following parturition. Anim. Behav., 18: 20-25.

16. Muul I., 1974: Geographic variation in the nesting habits of Glaucomys volans. J. Mamm., 55: 840-844.

17. Muul I. \& Alley J. W., 1963: Night gliders of woodlands. Nat. Hist., 72: $18-25$.

18. Myers P. \& Master L. L., 1986: The interpretation of variation in litter size and weights of young: three caveats. J. Mamm., 67: 572-575.

19. Nelson R. J., 1987: Photoperiod-nonresponsive morphs: a possible variable in microtine population-density fluctuations. Amer. Nat., 130: 350-369.

20. Odum E. P., 1955: An eleven year history of a Sigmodon population. J. Mamm., 36: $368-378$.

21. Pournelle G. H., 1952: Reproduction and early post-natal development of the cotton mouse, Peromyscus gossypinus gossypinus. J. Mamm., 31: 310-319.

22. Rand A. L. \& Host P., 1942: Mammal notes from Highland [sic] County, Florida. Results of Archbold Exped. 45, Bull. Amer. Mus. Nat. Hist., 80: $1-21$.

23. Sawyer S. L. \& Rose R. K., 1985: Homing in and ecology of the southern flying squirrel Glaucomys volans in southeastern Virginia. Amer. Midland Nat., 113: 238-244.

24. Siegel S., 1956: Nonparametric statistics for the behavioral sciences. McGrawHill Book Co., New York, $1-312$.

25. Sollberger D. E., 1943: Notes on the breeding habits of the eastern flying squirrel (Glaucomys volans volans). J. Mamm., 24: 163-173.

26. Sonenshine D. E., Lauer D. M., Walker T. C. \& Elisberg B. L., 1979: The ecology of Glaucomys volans (Linnaeus, 1758) in Virginia. Acta theriol., 24: $363-377$.

27. Uhlig H. G., 1956: Reproduction in the eastern flying squirrel in West Virginia. J. Mamm., 37: 295.

28. Wood F. E., 1910: A study of the mammals of Champaign County, Illinois, Bull. Illinois State Lab. Nat. Hist., 8: 501-613.

Received 16 January 1988, Accepted 5 June 1988. 
Mendi A. V. RAYMOND i James N. LAYNE

\section{ROZROD POLATUCHY GLAUCOMYS VOLANS NA FLORYDZIE}

\section{Streszczenie}

Badano sezon rozrodczy, wielkość miotów, stosunek plci w miocie oraz sukces rozrodezy u polatuchy, Glaucomys volans (Linnaeus, 1758), w południowo-centralnej części półwyspu Floryda w okresie od lipca 1979 do maja 1984. W badaniach wykorzystano domki gniazdowe.

Szacowane daty porodów dla 93 miotów od 81 samic zawieraly się w okresie od trzeciego tygodnia sierpnia do drugiego tygodnia stycznia z głównym szczytem przypadającym na sierpień - pierwsze dni września i wrzesień - pierwsze dni października oraz mniejszym szczytem w grudniu (Ryc. 1). Srednia wielkość miotu ze wszystkich lat badań wynosiła $3,0(1-6)$. Młodsze mioty charakteryzowały się większą średnią wielkością $(3,5)$ niż starsze $(2,8)$ (Tabela 1). W ciągu pięciu lat badań stwierdzono mniejszą zmienność czasu pierwszego porodu niż między rozkładem porodów w ciągu sezonu rozrodczego oraz datą ostatniego porodu w każdym roku. Sezon 1982-83 różnił się istotnie od innych lat (Ryc. 1). U 282 młodych ze wszystkich miotów stwierdzono $52 \%$ samców i $48 \%$ samic (Tabela 1). Wbrew wcześniejszym sugestiom nie znaleziono istotnych sezonowych różnic w stosunku płci w miotach $\boldsymbol{z}$ końca lata i początku zimy. W czasie stwierdzonej obecności na terenie badań spośród 81 samic -71 miało pojedyncze mioty, 8 miało dwa i 2 samice mialy trzy mioty. Zanotowano tylko 1 przypadek, w którym jedna samica prawdopodobnie wyprowadzila 2 mioty w jednym roku.

Uzyskane dane potwierdzają hipotezę, że sezon rozrodczy u polatuchy przesuwa się $\mathrm{z}$ wiosenno-jesiennego $\mathrm{w}$ północnych szerokościach do jesienno-zimowego w południowej części wschodniego zasięgu tego gatunku w Ameryce Pólnocnej (Ryc. 2). W przeciwieństwie do hipotezy o malejącej wielkości miotu wraz ze zmniejszającą się szerokością geograficzną stwierdzone w czasie tych badań wielkości miotów były większe, niż notowane w bardziej na północ polożonych rejonach (Tabela 2). 